\title{
Citizenship Norms and Tolerance in European Adolescents
}

\author{
Andrés Sandoval-Hernández, Ellen Claes, Nicola Savvides, \\ and Maria Magdalena Isac
}

\begin{abstract}
Within Europe, numerous political, economic, social, and cultural changes brought about by globalization and Europeanization have challenged and transformed young people's sense of citizenship and identity. An important aspect of good citizenship is attitudes of tolerance and support for the equal rights of others. Yet, in recent times, there has been a rise in the levels of intolerant and xenophobic attitudes, due, in part, to negative perceptions over increasing flows of migration, immigration, refugees, and asylum seekers. In this chapter, multiple group multinomial logistic regression models are estimated to determine how different profiles of citizenship norms (i.e., comprehensive, socially engaged, duty-based, monitorial, and anomic) relate to European adolescents' political tolerance, i.e., their attitudes towards equal rights of others (immigrants and women). Data from IEA's International Civic and Citizenship Education Study (ICCS) 2016, including 51,040 grade 8 students (aged 14) across 14 European countries was used. The study reveals two clear patterns. First, students classified within the comprehensive citizenship profile deal well with the ambivalence present in the definition of tolerance, especially regarding equal rights for immigrants. Second, students within the other citizenship
\end{abstract}

\footnotetext{
A. Sandoval-Hernández $(\varangle) \cdot$ N. Savvides

Department of Education, University of Bath, Bath, UK

e-mail: A.Sandoval@bath.ac.uk

N. Savvides

e-mail: N.Savvides@bath.ac.uk

E. Claes · M. M. Isac

KU Leuven, Centre for Political Science Research, Leuven, Belgium

e-mail: ellen.claes@kuleuven.be

M. M. Isac

e-mail: mariamagdalena.isac@kuleuven.be

M. M. Isac

INVALSI (Istituto Nazionale per la Valutazione del Sistema dell'Istruzione), Rome, Italy

(C) International Association for the Evaluation of Educational Achievement (IEA) 2021

E. Treviño et al. (eds.), Good Citizenship for the Next Generation,

International Association for the Evaluation of Educational Achievement (IEA)

Research for Education 12, https://doi.org/10.1007/978-3-030-75746-5_9
} 
profiles (socially engaged, duty-based, monitorial, and anomic) show significantly lower support for equal rights for immigrants than the students classified as comprehensive. The findings contribute toward understanding the mechanisms underpinning citizenship norms profiles and their relationship to attitudes toward others. The results may be used to inform targeted intervention policies for the promotion of tolerance in Europe.

Keywords Citizenship norms $\cdot$ Tolerance $\cdot$ Egalitarianism $\cdot$ International Civic and Citizenship Education Study (ICCS) - Multiple group multinomial logistic regression

\section{Introduction}

Within Europe, numerous political, economic, social, and cultural changes brought about by globalization and Europeanization have challenged and transformed young people's sense of citizenship and identity. An important aspect of good citizenship is attitudes of tolerance towards others (Almond and Verba 1963; Sherrod and Lauckhardt 2009), which includes positive attitudes towards the equal rights of others (Green et al. 2006). Yet, in recent times, we have witnessed rising levels of intolerant and xenophobic attitudes, due, in part, to negative perceptions over increasing flows of migration, immigration, refugees, and asylum seekers (Green et al. 2006).

According to Heater (1999), the feeling of citizenship points to the fact that how a person behaves in the political sphere is related to the ideas they have about "being a citizen." This feeling can, according to Heater, be a result of the person's identification with specific levels of political organization and, in a second vein, with their idea of civic virtue regarding the concept of a "good citizen." It is "citizenship" in the latter sense that we are interested in. Five profiles of citizenship norms (i.e., comprehensive, socially engaged, duty-based, monitorial, and anomic) were developed by Torres Irribarra and Carrasco (see Chap. 3) using latent class analysis on the International Association for the Evaluation of Educational Achievement (IEA) International Civic and Citizenship Education Study (ICCS) 2016 data. Drawing on their work, in the present chapter we used multiple group multinomial logistic regression models to investigate how these different profiles relate to European adolescents' political tolerance, i.e., their attitudes towards equal rights for others (immigrants and women). We used the ICCS 2016 data from 51,040 grade 8 students (aged 14) across 14 European countries.

This chapter is divided into five sections. Following this introduction, in the second section we provide a brief overview of the study's conceptual background, noting in particular the link between citizenship and tolerance. In section three, we describe the study's method in terms of the variables, the data used, and how the data was analysed. We present the results of the analysis in section four, showing interesting patterns regarding the association between different citizenship norms profiles and young people's level of tolerance (i.e., support for the equal rights of others). We end 
with discussion of the study's key conclusions in section five, noting theoretical and policy implications.

\section{Conceptual Background}

Within Europe, globalization and Europeanization have resulted in increasingly multicultural and ethnically diverse societies and challenged the concept of citizenship. National borders are increasingly blurred (Brodie 2004; O'Sullivan and Pashby 2008; Reid et al. 2010; Schattle 2012; Torres 2002) and citizenship has taken on new meanings beyond the nation state to include European and global dimensions. This, in turn, has challenged how young Europeans see themselves as citizens, particularly in terms of how they feel about their identities and their ideas about their roles and behaviors at the local, national, European, and global levels.

In addition to how they see themselves, how young Europeans see "others" is also being challenged. Europe has witnessed a large rise in the number of refugees and migrants from the Middle East and Africa attempting to enter the European Union. European surveys have highlighted increasingly negative public attitudes and insecurity over this perceived immigration "crisis," partly due to the rise in populist, far-right parties displaying anti-immigration rhetoric (Mylonas 2012). This public anxiety has resulted in the "othering" of minorities, a rise in racist attacks, and urban unrest that has been attributed to the cultural difference and deviancy of young migrants (Schierup and Ålund 2011, p. 56). It has also contributed to anti-European integration sentiment that, among other issues, resulted in Brexit.

The societal changes outlined have been perceived of as posing a challenge to existing value systems, making it difficult to accept new citizens, thereby complicating their integration process (Freitag and Rapp 2015). In terms of the inclusion of newcomers, some countries have chosen to implement restrictive citizenship legislation, while others have taken a more liberal approach (Midtbøen 2015). In addition, there has been a focus on citizenship initiatives that promote integration, social cohesion, and values such as tolerance and respect for cultural diversity, inclusion, equal rights, and human rights (Sampermans et al. 2017). However, efforts towards promoting these at the national level have varied considerably. For example, in England, the focus has been on learning about Fundamental British Values (FBVs) in an effort to prevent radicalization and extremism following the rise in terrorist attacks. This initiative has been criticized for potentially alienating and radicalizing students who do not see themselves as truly British (Bolloten and Richardson 2015).

It is clear that an important aspect of good citizenship is the attitude of tolerance towards others (Almond and Verba 1963; Sherrod and Lauckhardt 2009). Tolerance is a multidimensional concept, which includes a wide range of attitudes towards different groups that may take various forms (Green et al. 2006; Isac et al. 2018). For example, political tolerance refers to giving different groups in society democratic and political rights, whereas social tolerance is related to contact with "others" (e.g., inter-ethnic friendships) (Isac et al. 2018). According to Gibson (2007), tolerance can 
be defined as: "the willingness to put up with disagreeable ideas and groups in order to peacefully coexist." Without tolerance, not all groups in society would be able to defend their interests in the same way, which in turn could challenge the existence of a true democracy. Moreover, without tolerance, inter-group conflict would become practically inevitable, thus heightening even more the importance of tolerance as a fundamental democratic attitude (Hanh 1998). By definition, tolerance contains an internal paradox of allowing the ideas or interests one disagrees with, dislikes, or abhors, while also giving equal rights to people or groups regardless of whether you agree with their opinion or behaviour (Sullivan and Transue 1999; Sullivan et al. 1981; Vogt 1997). For example, as a citizen you can disagree with an idea because of political, religious, cultural, or social beliefs. However, you still allow people to express this idea and endorse their fundamental equal rights.

In light of this background and given the importance of tolerance for good citizenship and well-functioning democracies (Council of Europe 2010), we operationalize tolerance in terms of positive attitudes towards the equal rights of (a) women and (b) immigrants. In the next section, we explain the methods used to determine how different profiles of citizenship norms amongst European adolescents relate to attitudes towards these two groups.

\section{Method}

This section describes the methods and data used for the analysis presented in this chapter. Because of our focus on Europe, we used only the data from the 14 European countries that participated in ICCS 2016 (Bulgaria, Croatia, Estonia, Latvia, Lithuania, Slovenia, Denmark, Finland, Norway, Sweden, Italy, Malta, Belgium (Flemish), the Netherlands) (Schulz et al. 2018a). The sample is representative of the population of grade 8 students (average age 14) in each country and included a total of 51,040 students.

We used multiple group multinomial logistic regression models to determine how different profiles of citizenship norms relate to European adolescents' attitudes towards equal rights for immigrants and women. The dependent variable was the student profiles of "good citizenship" developed in Chap. 3. Using latent class analysis, Torres Irribara and Carrasco (the present volume) used ICCS 2016 data to look at how students endorse particular citizenship norms (see Chap. 3 for a full list of the different norms) classifying them into five types of citizenship norms profile: (a) comprehensive, (b) socially engaged, (c) duty-based, (d) monitorial, and (e) anomic.

Students classed within the comprehensive citizenship profile (who were in fact the largest group) are those who value different forms of civic engagement (Ekman and Amnå 2012) including manifest forms of participation, such as voting, extra parliamentary actions such as peaceful protests, and social involvement such as helping in the local community. Students classed as socially engaged consider it important to protect the environment, protect human rights, and participate in activities that benefit the local community. They also highly value obedience to the law 
and respect for government representatives although they consider it less important to participate in political discussions or join a political party. Those who fall within the duty-based profile find it important to obey the law, work hard, and respect government authorities. However, they score lower on other characteristics such as participation in non-institutionalized forms of political participation such as activities to protect the environment, protect human rights, and benefit people in the local community. They also consider it less important to join a political party, participate in political discussions, and engage in peaceful protests. The monitorial group represent a mix of valuing non-conventional forms of political participation, while disregarding engaging in political parties. They value participation in elections as well as non-institutionalized forms of political participation, such as peaceful protest against unjust laws, participation in activities that benefit the local community, promotion of human rights, and protection of the environment. The anomic group expressed the lowest endorsement to all the citizenship norms, i.e., they consistently had the lowest probability of answering "important" across all the items. The most valued items for the anomic group are obeying the law and working hard, although the rate of endorsement is too low to be considered typical of this group.

The main independent variables were students' attitudes towards equal rights for immigrants and women. These variables correspond to scales created by replicating the procedure used by Isac et al. (2019). We created these scales instead of using those included in the ICCS 2016 dataset, because the modifications proposed by Isac et al. ensure cross-cultural comparability of the resulting scores across the 14 countries included in the analysis. We used three indicators to construct the scale of attitudes towards equal rights for women. An example of such an indicator includes equality of opportunity in the labour market. We used four indicators to construct the scale of attitudes towards equal rights for immigrants, an example of which is equality of opportunity for political participation (see Table 1 for the full list of indicators).

The fit indices of the scalar model largely comply with the model fit evaluation criteria (see Brown 2014; Wang and Wang 2012), both in terms of overall fit indices $(\mathrm{RMSEA}=0.043 ; \mathrm{CFI}=0.985 ; \mathrm{TLI}=0.987)$, as well as relative fit indices (Metric vs Configural; $\triangle \mathrm{RMSEA}=0.010 ; \Delta \mathrm{CFI}=0.005)$. The full procedures and results of the Multi Group Confirmatory Factor Analysis (MG-CFA) models used to create and test the invariance of the two scales, can be consulted in Isac et al. (2019).

Apart from attitudes towards equal rights for immigrants and women, other independent variables used in the analysis were student gender, home literacy resources, civic knowledge, and immigrant status (see Table 2 for the main characteristics of these variables). These variables were included as covariates in the analysis since they have been shown to be important predictors of the independent variable in previous studies (see, for example, Hooghe et al. 2015, 2016).

We report the odds (i.e., the relative probabilities) of belonging to each of the profiles with reference to each of the independent variables. In the present model, we use the largest group, i.e., the comprehensive citizen, as the reference category. The fitted model assesses the change in odds, for one unit of every covariate included in the model. In particular, we are interested in how students endorse citizenship norms, conditional to their attitudes towards equal rights for immigrants and for women. For 
Table 1 Indicators in the analysis of attitudes towards women and immigrants

\begin{tabular}{l|l}
\hline Item code & Item text \\
\hline \multicolumn{2}{l}{ Attitudes towards equal rights for women } \\
\hline IS3G24C* & Women should stay out of politics \\
\hline IS3G24D* & $\begin{array}{l}\text { When there are not many jobs available, men should have more right to a job than } \\
\text { women }\end{array}$ \\
\hline IS3G24F* & Men are better qualified to be political leaders than women \\
\hline Attitudes towards equal rights for immigrants \\
\hline ES3G04B & $\begin{array}{l}\text { Immigrant children should have the same opportunities for education that other } \\
\text { children in the country have }\end{array}$ \\
\hline ES3G04C & $\begin{array}{l}\text { Immigrants who live in a country for several years should have the opportunity to } \\
\text { vote in elections }\end{array}$ \\
\hline ES3G04D & $\begin{array}{l}\text { Immigrants should have the opportunity to continue their own customs and } \\
\text { lifestyle }\end{array}$ \\
\hline ES3G04E & \begin{tabular}{l} 
Immigrants should have the same rights that everyone else in the country has \\
\hline
\end{tabular}
\end{tabular}

Notes * Item reverse coded so that lower values reflect negative attitudes

Response categories: $1=$ Strongly disagree; $2=$ Disagree; $3=$ Agree; $4=$ Strongly agree

Source ICCS 2016 technical report (Schulz et al. 2018b)

example, the model tells us if the odds of being socially engaged are higher than being comprehensive, when students present higher levels of support for equal rights for women. No constraints between countries were added, so the relationship between the variables of interest are freely estimated.

All estimates include the complex sample design of ICCS 2016. Taylor Series Linearization was used for variance estimation, including school stratification and schools as the primary sampling unit (Stapleton 2013). Survey weights were scaled as up to 500 observations to ensure the equal contribution of each country to the results (Gonzalez 2012). Civic knowledge plausible values were included as imputed data, to account for its measurement error in all calculations (Rutkowski et al. 2010). Data preparation was carried out using the IEA IDB Analyzer (IEA 2017) and IBM SPSS (IBM 2015). All analyses were performed in Mplus 8.2 (Muthén and Muthén 2017). The full information maximum likelihood (FIML) method was implemented to handle missing data. Only 297 cases with missing data on all variables were not included in the analysis.

\section{Results}

The main focus of the present chapter is the relationship between students' attitudes towards equal rights for women and for immigrants, and their associations with students' citizenship norms endorsement. We present the estimates for the associations of these two variables for each country, while controlling for students' gender, 
Table 2 Independent variables

\begin{tabular}{|c|c|c|}
\hline Variable name & Type & Description \\
\hline $\begin{array}{l}\text { Attitudes towards equal rights } \\
\text { for immigrants }\end{array}$ & $\begin{array}{l}\text { Continuous Standardized } \\
\text { within countries }\end{array}$ & $\begin{array}{l}\text { Student attitudes toward equal } \\
\text { rights for immigrants. Own } \\
\text { computations based on Multi } \\
\text { Group Confirmatory Factor } \\
\text { Analysis across } 14 \text { European } \\
\text { countries. Mean of } 0 \text { and } \\
\text { standard deviation of } 1\end{array}$ \\
\hline $\begin{array}{l}\text { Attitudes towards equal rights } \\
\text { for women }\end{array}$ & $\begin{array}{l}\text { Continuous Standardized } \\
\text { within countries }\end{array}$ & $\begin{array}{l}\text { Student attitudes toward equal } \\
\text { rights for women. Own } \\
\text { computations based on Multi } \\
\text { Group Confirmatory Factor } \\
\text { Analysis across } 14 \text { European } \\
\text { countries. Mean of } 0 \text { and } \\
\text { standard deviation of } 1\end{array}$ \\
\hline Student gender & Dummy & Female $=1$, male $=0$ \\
\hline $\begin{array}{l}\text { Socioeconomic status of the } \\
\text { students }\end{array}$ & $\begin{array}{l}\text { Continuous Standardized } \\
\text { within countries }\end{array}$ & $\begin{array}{l}\text { National index of } \\
\text { socioeconomic background } \\
\text { derived from the following three } \\
\text { indices: highest occupational } \\
\text { status of parents (S_HISEI), } \\
\text { highest educational level of } \\
\text { parents (S_HISCED), and the } \\
\text { number of books at home } \\
\text { (S_HOMLIT). This index was } \\
\text { then standardized within } \\
\text { countries to have a mean of } 0 \\
\text { and standard deviation of } 1\end{array}$ \\
\hline Civic knowledge & $\begin{array}{l}\text { Continuous Standardized } \\
\text { within countries }\end{array}$ & $\begin{array}{l}\text { Student scores on the civic } \\
\text { knowledge test. Five plausible } \\
\text { values. Mean of } 500 \text { and } \\
\text { standard deviation of } 100\end{array}$ \\
\hline
\end{tabular}

Source ICCS 2016 technical report (Schulz et al. 2018b)

SES, civic knowledge, and immigrant status (see Tables 3, 4, and 5). Because of space constraints, in these three results tables we present the logits and odds for students' attitudes towards equal rights for women and for immigrants' only. The coefficients of the other predictors included in the model are available as an appendix (see Appendix C).

The analyses of the data show some interesting general patterns regarding attitudes towards equal rights for immigrants and women. First, in the case of support for equal rights for women, the strongest associations between this variable and the different citizenship profiles were found in Sweden and the Netherlands. In both countries, the odds of being socially engaged were higher than the odds of being comprehensive. In Sweden this was $37 \%$, and in the Netherlands $36 \%$. 
Table 3 Results of the multiple group multinomial logistic regression model: Central and Eastern countries

\begin{tabular}{|c|c|c|c|c|c|c|c|c|c|c|c|c|}
\hline & \multicolumn{3}{|c|}{$\begin{array}{l}\mathrm{C} 1 \text { : Socially } \\
\text { engaged }\end{array}$} & \multicolumn{3}{|c|}{ C2: Duty-based } & \multicolumn{3}{|c|}{ C3: Monitorial } & \multicolumn{3}{|c|}{ C4: Anomic } \\
\hline & E & OR & & $\mathrm{E}$ & OR & & E & OR & & E & OR & \\
\hline \multicolumn{13}{|l|}{ Bulgaria } \\
\hline $\begin{array}{l}\text { Equal } \\
\text { rights for } \\
\text { women }\end{array}$ & 0.24 & 1.27 & $* * *$ & 0.28 & 1.33 & & 0.23 & 1.26 & $* *$ & 0.38 & 1.46 & $* *$ \\
\hline $\begin{array}{l}\text { Equal } \\
\text { rights for } \\
\text { immigrants }\end{array}$ & -0.20 & 0.82 & $* * *$ & -0.27 & 0.76 & & -0.49 & 0.61 & $* * *$ & -0.73 & 0.48 & $* * *$ \\
\hline \multicolumn{13}{|l|}{ Croatia } \\
\hline $\begin{array}{l}\text { Equal } \\
\text { rights for } \\
\text { women }\end{array}$ & 0.06 & 1.07 & & -0.16 & 0.85 & & -0.31 & 0.73 & $* *$ & -0.07 & 0.94 & \\
\hline $\begin{array}{l}\text { Equal } \\
\text { rights for } \\
\text { immigrants }\end{array}$ & -0.12 & 0.89 & $* *$ & -0.42 & 0.66 & $* * *$ & -0.35 & 0.70 & $* *$ & -0.68 & 0.51 & $* * *$ \\
\hline \multicolumn{13}{|l|}{ Estonia } \\
\hline $\begin{array}{l}\text { Equal } \\
\text { rights for } \\
\text { women }\end{array}$ & 0.08 & 1.08 & & 0.00 & 1.00 & & -0.05 & 0.95 & & 0.07 & 1.07 & \\
\hline $\begin{array}{l}\text { Equal } \\
\text { rights for } \\
\text { immigrants }\end{array}$ & -0.13 & 0.88 & + & -0.17 & 0.85 & + & -0.33 & 0.72 & $* * *$ & -0.24 & 0.79 & + \\
\hline \multicolumn{13}{|l|}{ Latvia } \\
\hline $\begin{array}{l}\text { Equal } \\
\text { rights for } \\
\text { women }\end{array}$ & 0.03 & 1.03 & & -0.15 & 0.86 & + & -0.03 & 0.97 & & -0.03 & 0.98 & \\
\hline $\begin{array}{l}\text { Equal } \\
\text { rights for } \\
\text { immigrants }\end{array}$ & -0.15 & 0.86 & $* *$ & -0.27 & 0.76 & $* * *$ & -0.22 & 0.80 & $* *$ & -0.59 & 0.56 & $* * *$ \\
\hline \multicolumn{13}{|l|}{ Lithuania } \\
\hline $\begin{array}{l}\text { Equal } \\
\text { rights for } \\
\text { women }\end{array}$ & 0.13 & 1.14 & $* *$ & 0.05 & 1.06 & & 0.03 & 1.03 & & 0.08 & 1.08 & \\
\hline $\begin{array}{l}\text { Equal } \\
\text { rights for } \\
\text { immigrants }\end{array}$ & 0.02 & 1.02 & & -0.14 & 0.87 & $* *$ & -0.34 & 0.71 & $* * *$ & -0.50 & 0.60 & $* *$ \\
\hline \multicolumn{13}{|l|}{ Slovenia } \\
\hline $\begin{array}{l}\text { Equal } \\
\text { rights for } \\
\text { women }\end{array}$ & 0.05 & 1.05 & & -0.11 & 0.90 & & -0.13 & 0.88 & & 0.01 & 1.01 & \\
\hline
\end{tabular}


Table 3 (continued)

\begin{tabular}{l|l|l|l|l|l|l|l|l|l|l|l|l}
\hline & \multicolumn{3}{l|}{$\begin{array}{l}\text { C1: Socially } \\
\text { engaged }\end{array}$} & \multicolumn{4}{l|}{ C2: Duty-based } & \multicolumn{3}{l|}{ C3: Monitorial } & \multicolumn{3}{l}{ C4: Anomic } \\
\cline { 2 - 13 } & E & OR & & E & OR & & E & OR & & E & OR & \\
\hline $\begin{array}{l}\text { Equal } \\
\text { rights for } \\
\text { immigrants }\end{array}$ & -0.15 & 0.86 & $* *$ & -0.48 & 0.62 & $* * *$ & -0.38 & 0.68 & $* * *$ & -0.56 & 0.57 & $* * *$ \\
\hline
\end{tabular}

Notes $\mathrm{C} 5$ : Comprehensive is the reference category. $\mathrm{E}=$ Estimated coeffcients, $\mathrm{OR}=$ Odds ratio, $* * *=\mathrm{p}<0.001, * *=\mathrm{p}<0.01, *=\mathrm{p}<0.05,+=\mathrm{p}<0.10$

We now describe the results for each of the profiles with a focus on the relationship between students' attitudes towards equal rights for women over and above the other covariates i.e., student gender, socioeconomic status, civic knowledge, and immigrant status (see Tables 3, 4, and 5).

The odds of students being classified as socially engaged (as compared to comprehensive) were significantly higher as their support for equal rights for women increased in half of the countries included in the analysis (i.e., Bulgaria, Lithuania, Finland, Norway, Sweden, Malta, and the Netherlands). This association was not statistically significant in the rest of the countries (Croatia, Estonia, Latvia, Slovenia, Denmark, Italy, and Belgium (Flemish)).

In terms of the comparison with comprehensive students, the odds of students being classified as duty-based were significantly higher as their support for equal rights for women increased in the Netherlands. Conversely, in Latvia, the odds of students being classified as duty-based were significantly higher as their support for equal rights for women decreased. In the rest of the countries, this relationship was not statistically significant.

Using the comprehensive students as a reference group, the odds of students being monitorial were significantly higher as their support for equal rights for women decreased in Croatia, Denmark, Norway, Italy, and Belgium (Flemish). On the contrary, in Bulgaria, students have higher odds of being monitorial when their support for equal rights for women is higher than that of comprehensive students. In the rest of the countries, this association is not statistically significant.

The odds of students being classified as anomic rather than comprehensive are significantly higher as their support for equal rights for women increased in Bulgaria. In Belgium (Flemish), by contrast, the odds of students being classified as anomic (as compared to comprehensive students) were significantly higher as their support for equal rights for women decreased. In the rest of the countries, this relationship was not statistically significant. 
Table 4 Results of the multiple group multinomial logistic regression model: Nordic and Southern countries

\begin{tabular}{|c|c|c|c|c|c|c|c|c|c|c|c|c|}
\hline & \multicolumn{3}{|c|}{$\begin{array}{l}\mathrm{C} 1 \text { : Socially } \\
\text { engaged }\end{array}$} & \multicolumn{3}{|c|}{ C2: Duty-based } & \multicolumn{3}{|c|}{ C3: Monitorial } & \multicolumn{3}{|c|}{ C4: Anomic } \\
\hline & $\mathrm{E}$ & OR & & E & OR & & $\mathrm{E}$ & OR & & $\mathrm{E}$ & OR & \\
\hline \multicolumn{13}{|l|}{ Denmark } \\
\hline $\begin{array}{l}\text { Equal } \\
\text { rights for } \\
\text { women }\end{array}$ & 0.06 & 1.06 & & -0.04 & 0.96 & & -0.24 & 0.79 & + & -0.15 & 0.86 & \\
\hline $\begin{array}{l}\text { Equal } \\
\text { rights for } \\
\text { immigrants }\end{array}$ & -0.17 & 0.84 & $* *$ & -0.29 & 0.75 & $* * *$ & -0.17 & 0.85 & & -0.39 & 0.68 & $* *$ \\
\hline
\end{tabular}

\begin{tabular}{|c|c|c|c|c|c|c|c|c|c|c|c|c|}
\hline \multicolumn{13}{|l|}{ Finland } \\
\hline $\begin{array}{l}\text { Equal } \\
\text { rights for } \\
\text { women }\end{array}$ & 0.24 & 1.27 & $* *$ & 0.07 & 1.08 & & -0.11 & 0.90 & & 0.20 & 1.23 & \\
\hline $\begin{array}{l}\text { Equal } \\
\text { rights for } \\
\text { immigrants }\end{array}$ & -0.34 & 0.71 & $* * *$ & -0.59 & 0.56 & $* * *$ & -0.62 & 0.54 & $* * *$ & -1.08 & 0.34 & $* * *$ \\
\hline \multicolumn{13}{|l|}{ Norway } \\
\hline $\begin{array}{l}\text { Equal } \\
\text { rights for } \\
\text { women }\end{array}$ & 0.17 & 1.18 & $* * *$ & 0.05 & 1.05 & & -0.19 & 0.83 & $* *$ & -0.07 & 0.93 & \\
\hline $\begin{array}{l}\text { Equal } \\
\text { rights for } \\
\text { immigrants }\end{array}$ & -0.22 & 0.80 & $* * *$ & -0.42 & 0.66 & *** & -0.35 & 0.71 & $* * *$ & -0.85 & 0.43 & $* * *$ \\
\hline \multicolumn{13}{|l|}{ Sweden } \\
\hline $\begin{array}{l}\text { Equal } \\
\text { rights for } \\
\text { women }\end{array}$ & 0.31 & 1.37 & $* * *$ & 0.05 & 1.05 & & -0.12 & 0.89 & & 0.17 & 1.19 & \\
\hline $\begin{array}{l}\text { Equal } \\
\text { rights for } \\
\text { immigrants }\end{array}$ & -0.27 & 0.76 & $* * *$ & -0.46 & 0.63 & $* * *$ & -0.47 & 0.62 & $* * *$ & -0.82 & 0.44 & $* * *$ \\
\hline \multicolumn{13}{|l|}{ Italy } \\
\hline $\begin{array}{l}\text { Equal } \\
\text { rights for } \\
\text { women }\end{array}$ & -0.05 & 0.95 & & -0.11 & 0.90 & & -0.26 & 0.77 & $* *$ & -0.20 & 0.82 & \\
\hline $\begin{array}{l}\text { Equal } \\
\text { rights for } \\
\text { immigrants }\end{array}$ & -0.22 & 0.81 & $* *$ & -0.55 & 0.58 & $* * *$ & -0.54 & 0.58 & $* * *$ & -1.28 & 0.28 & $* * *$ \\
\hline \multicolumn{13}{|l|}{ Malta } \\
\hline $\begin{array}{l}\text { Equal } \\
\text { rights for } \\
\text { women }\end{array}$ & 0.19 & 1.21 & $* *$ & 0.06 & 1.06 & & -0.11 & 0.90 & & 0.00 & 1.00 & \\
\hline
\end{tabular}


Table 4 (continued)

\begin{tabular}{l|l|l|l|l|l|l|l|l|l|l|l|l}
\hline & \multicolumn{3}{l|}{$\begin{array}{l}\text { C1: Socially } \\
\text { engaged }\end{array}$} & \multicolumn{3}{l|}{ C2: Duty-based } & \multicolumn{3}{l|}{ C3: Monitorial } & \multicolumn{3}{l}{ C4: Anomic } \\
\cline { 2 - 13 } & E & OR & & E & OR & & E & OR & & E & OR & \\
\hline $\begin{array}{l}\text { Equal } \\
\text { rights for } \\
\text { immigrants }\end{array}$ & -0.20 & 0.82 & $* * *$ & -0.42 & 0.65 & $* * *$ & -0.49 & 0.61 & $* * *$ & -0.64 & 0.53 & $* * *$ \\
\hline
\end{tabular}

Notes $\mathrm{C} 5$ : Comprehensive is the reference category. $\mathrm{E}=$ Estimated coeffcients, $\mathrm{OR}=$ Odds ratio, $* * *=\mathrm{p}<0.001, * *=\mathrm{p}<0.01, *=\mathrm{p}<0.05,+=\mathrm{p}<0.10$

Table 5 Results of the multiple group multinomial logistic regression model: Western countries

\begin{tabular}{|c|c|c|c|c|c|c|c|c|c|c|c|c|}
\hline & \multicolumn{3}{|c|}{$\begin{array}{l}\mathrm{C} 1 \text { : Socially } \\
\text { engaged }\end{array}$} & \multicolumn{3}{|c|}{ C2: Duty-based } & \multicolumn{3}{|c|}{ C3: Monitorial } & \multicolumn{3}{|c|}{ C4: Anomic } \\
\hline & $\mathrm{E}$ & OR & & $\mathrm{E}$ & OR & & E & OR & & E & OR & \\
\hline \multicolumn{13}{|c|}{ Belgium (Flemish) } \\
\hline $\begin{array}{l}\text { Equal } \\
\text { rights for } \\
\text { women }\end{array}$ & 0.09 & 1.09 & & -0.07 & 0.94 & & -0.36 & 0.70 & $* *$ & -0.34 & 0.71 & $* *$ \\
\hline $\begin{array}{l}\text { Equal } \\
\text { rights for } \\
\text { immigrants }\end{array}$ & -0.27 & 0.77 & $* * *$ & -0.62 & 0.54 & $* * *$ & -0.62 & 0.54 & $* * *$ & -0.78 & 0.46 & $* * *$ \\
\hline \multicolumn{13}{|c|}{ The Netherlands } \\
\hline $\begin{array}{l}\text { Equal } \\
\text { rights for } \\
\text { women }\end{array}$ & 0.31 & 1.36 & $* * *$ & 0.26 & 1.30 & $* *$ & 0.07 & 1.07 & & 0.36 & 1.43 & $* *$ \\
\hline $\begin{array}{l}\text { Equal } \\
\text { rights for } \\
\text { immigrants }\end{array}$ & -0.23 & 0.80 & $* *$ & -0.43 & 0.65 & $* * *$ & -0.48 & 0.62 & $* * *$ & -1.00 & 0.37 & $* * *$ \\
\hline
\end{tabular}

Notes $\mathrm{C} 5$ : Comprehensive is the reference category. $\mathrm{E}=$ Estimated coeffcients, $\mathrm{OR}=$ Odds ratio, $* * *=\mathrm{p}<0.001, * *=\mathrm{p}<0.01, *=\mathrm{p}<0.05,+=\mathrm{p}<0.10$

Second, in the case of support for equal rights for immigrants, the strongest and more consistent associations were found with the odds of belonging to the anomic class in Finland, Italy, and the Netherlands (66\%, 73\%, and 64\%, respectively).

Another interesting pattern is that, when compared to comprehensive students, lower support for equal rights for immigrants is associated with higher odds of belonging to almost all the other classes in the vast majority of countries. The only exceptions are: socially-engaged students in Lithuania, duty-based students in Bulgaria, and monitorial students in Denmark, where support for equal rights for immigrants does not establish a statistically significant association. 
There is also a pattern indicating that the probability of belonging to the monitorial and anomic groups has a stronger (i.e., negative) association with the support for equal rights for immigrants. Support for equal rights for women, tends to establish a weaker pattern regarding the odds of belonging to the classes included in the analysis. Using comprehensive students as the reference group, it increases the odds of students being socially engaged in seven countries, decreases the odds of being monitorial in five countries, and makes a significant difference in belonging to the other two groups (duty-based and anomic) in two countries. However, for the last two groups, the direction of the association is mixed (positive in one country and negative in the other).

\section{Discussion and Conclusion}

Considering how young people perceive themselves interacting with democracy from a politically normative point of view-in Heater's terminology, their "feeling" of what citizenship should/should not be like-this chapter uses the five citizenship norms profiles that are present amongst European young people (see Chap. 3). Most grade 8 students in Europe were categorized within the comprehensive citizenship profile, while socially-engaged, duty-based, monitorial, and anomic groups were also identified. In studying the relationship of these citizenship norms with the tolerance concept that was operationalized by levels of support for equal rights for women and immigrants, two clear patterns emerged.

First, regarding the support for equal rights for women, we established that by using comprehensive students as the reference group, the odds of students being socially engaged increase in seven countries, the odds of being monitorial decrease in five countries, and makes a significant difference in belonging to the other two groups (duty-based and anomic) in two countries. However, for the last two groups, the direction of the association is mixed (positive in one country and negative in the other). We can hence conclude that the relationship between the five citizenship norms profiles and the first operationalization of tolerance (i.e., support for equal rights for women) is not consistent in Europe. However, the hypothesis that especially the socially engaged are the most open to equal rights for women seems to hold for at least seven countries.

Second, looking into equal rights for immigrants, it is clear that the comprehensive group deals well with the ambivalence present in the definition of tolerance. This group scores high on all the indicators of good citizenship and seems to be able to agree to disagree with others, and hence also to work with immigrant groups towards higher social cohesion in Europe. The other groups do not seem to accept the paradox of giving equal rights to people or groups regardless of whether you agree with their 
opinion or behaviour. The duty-based, monitorial, anomic, and even the sociallyengaged groups, show significantly lower support for equal rights for immigrants than the students classified as comprehensive. This relationship was expected for groups such as the duty-based students, while their political activities are mostly related to democracy's social order. This can imply a very narrow interpretation of rights of non-Europeans in Europe. Also, for the monitorial and anomic groups, this outcome comes as no surprise, as these two types of citizens seem to be more focused on the local, personal level (Westheimer and Kahne 2007) rather than opening themselves to a larger, globalized, more diverse world. As for students in the socially-engaged group, who theoretically are described as being concerned about social needs, human rights, and the environment (Dalton 2008; Barber and Ross 2018), we expected more young people to be part of this group (Dejaeghere and Hooghe 2009; Hooghe and Oser 2015; Reichert 2016) and we also hypothesized a higher inclination to support equal rights for immigrants. However, it seems that this group is also more focused on their local (maybe more homogenous) community, rights, and the environment, and that they seem to "hunker down" (Putnam 2007), making them engaged in their own group, but not inclined to be open to more equal rights for immigrants than the comprehensive group.

The results of the study have both theoretical and policy implications. In terms of the theoretical implications, the results develop understanding of the mechanisms underpinning the relationship between young European adolescents' feelings about citizenship and their attitudes towards others (specifically immigrants and women). It is worth highlighting that our results indicate there is no single citizenship profile that endorses all the democratic values analyzed in this chapter. Rather, the endorsement of different democratic values is dependent on students' individual views regarding how a good citizen is defined. In terms of policy implications, given the current European political climate characterized by increasingly negative perceptions of immigrants, our results suggest the need to develop targeted policy interventions for the promotion of tolerance and equal rights for others amongst young Europeans.

\section{Appendix C}

See Tables 6, 7, 8 and 9. 


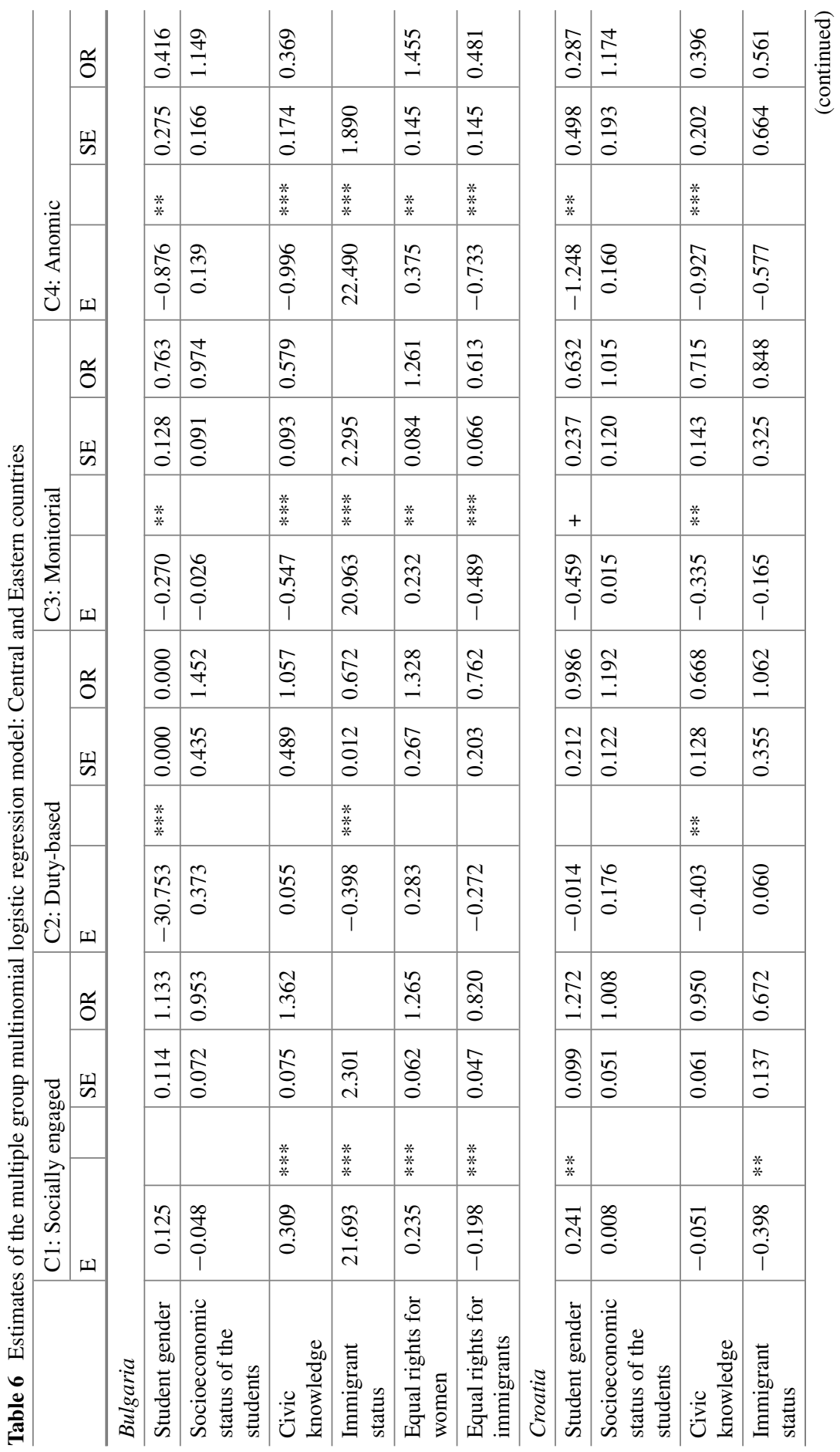




\begin{tabular}{|c|c|c|c|c|c|c|c|c|c|c|c|c|c|}
\hline \multirow{4}{*}{ 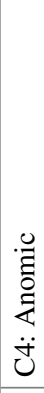 } & 임 & $\hat{\widehat{o}}$ & $\begin{array}{l}8 \\
\text { ô } \\
0 \\
0\end{array}$ & & $\begin{array}{l}\text { Ò } \\
\stackrel{+}{+} \\
0\end{array}$ & $\stackrel{ }{\stackrel{N}{0}}$ & 导 & 号 & $\stackrel{n}{\tilde{S}}$ & 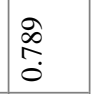 & & $\begin{array}{c}\hat{\infty} \\
\stackrel{0}{0} \\
0\end{array}$ & 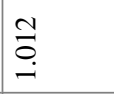 \\
\hline & $\sqrt[\omega]{2}$ & 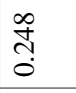 & $\frac{0}{5}$ & & 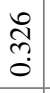 & 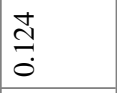 & $\stackrel{n}{\frac{n}{0}}$ & $\hat{n}$ & $\begin{array}{l}5 \\
0 \\
0\end{array}$ & $\frac{P}{\stackrel{9}{0}}$ & & 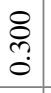 & $\stackrel{0}{\stackrel{1}{\prime}}$ \\
\hline & & & 蕃 & & * & $\stackrel{*}{*}$ & 蕃 & & & + & & & \\
\hline & 디 & $\begin{array}{l}2 \\
8 \\
0 \\
0 \\
1\end{array}$ & $\begin{array}{l}0 \\
0 \\
0 \\
0 \\
1\end{array}$ & & $\begin{array}{c}\bar{\sigma} \\
\dot{a} \\
i\end{array}$ & 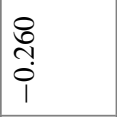 & $\begin{array}{l}\vec{\sigma} \\
\infty \\
0 \\
1\end{array}$ & ๙ָ & 号 & $\begin{array}{l}\hat{\tilde{n}} \\
\hat{i} \\
i\end{array}$ & & 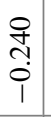 & $\stackrel{2}{\stackrel{2}{0}}$ \\
\hline \multirow{4}{*}{ 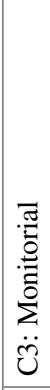 } & ชै & 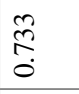 & 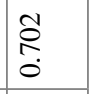 & & $\begin{array}{c}\stackrel{0}{0} \\
0 \\
0\end{array}$ & $\begin{array}{l}n \\
\infty \\
\vdots \\
0\end{array}$ & 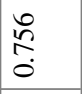 & $\stackrel{8}{=}$ & 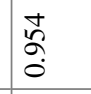 & $\overrightarrow{\mathbb{N}}$ & & $\begin{array}{l}0 \\
\text { ఏ. } \\
0\end{array}$ & 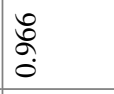 \\
\hline & 岳 & 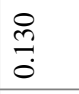 & $\stackrel{0}{0}$ & & $\begin{array}{l}\infty \\
m \\
0 \\
0\end{array}$ & 志 & $\stackrel{m}{\Xi}$ & 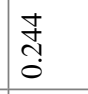 & $\frac{8}{0}$ & 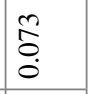 & & $\begin{array}{l}\overparen{\jmath} \\
\stackrel{0}{0}\end{array}$ & ర్రి \\
\hline & & $\stackrel{*}{*}$ & * & & & * & * & & & $\stackrel{*}{*}$ & & * & \\
\hline & 디 & $\begin{array}{l}\stackrel{0}{m} \\
\text { ma } \\
\stackrel{1}{1}\end{array}$ & 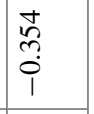 & & $\begin{array}{l}\grave{1} \\
\overrightarrow{0} \\
1\end{array}$ & 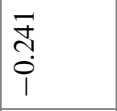 & $\begin{array}{l}0 \\
\infty \\
\\
0 \\
1\end{array}$ & $\frac{⿱}{n}$ & $\begin{array}{l}\tilde{f} \\
\text { Oे } \\
\dot{0}\end{array}$ & 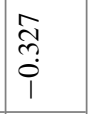 & & $\mid \begin{array}{c}0 \\
0 \\
\tilde{n} \\
0 \\
1\end{array}$ & 志 \\
\hline \multirow{4}{*}{ 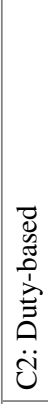 } & ํㅡㅇ & 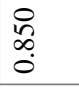 & 萬 & & 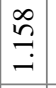 & $\begin{array}{l}\hat{2} \\
\infty \\
0 \\
0\end{array}$ & $\frac{\Re}{\stackrel{2}{0}}$ & 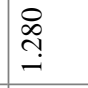 & $\stackrel{\infty}{\circ}$ & \begin{tabular}{l}
1 \\
\multirow{2}{*}{} \\
$\infty$ \\
0 \\
0
\end{tabular} & & $\stackrel{\text { }}{\beth}$ & 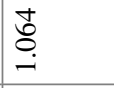 \\
\hline & $\sqrt[1]{2}$ & $\stackrel{m}{=}$ & $\stackrel{ \pm}{\Xi}$ & & $\begin{array}{l}\text { 导 } \\
\stackrel{0}{0}\end{array}$ & 홍 & $\begin{array}{l}0 \\
0 \\
0\end{array}$ & 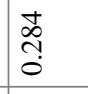 & $\begin{array}{l}0 \\
\infty \\
0 \\
0\end{array}$ & @̊ & & $\begin{array}{l}\vec{J} \\
\ddot{0}\end{array}$ & Ỗ. \\
\hline & & & $\stackrel{*}{*}$ & & & & * & & & + & & & \\
\hline & 디 & $\frac{\sqrt[6]{6}}{\frac{1}{1}}$ & $\frac{n}{j}$ & & $\begin{array}{c}0 \\
\stackrel{9}{9} \\
0\end{array}$ & $\begin{array}{l}\infty \\
0 \\
0 \\
0 \\
1\end{array}$ & $\begin{array}{l}0 \\
\text { } \\
i \\
i \\
1\end{array}$ & ָ̊ & $\begin{array}{l}0 \\
\delta \\
0 \\
0 \\
1\end{array}$ & $\frac{\infty}{0}$ & & $\stackrel{\infty}{=}$ & $\underset{0}{0}$ \\
\hline \multirow{5}{*}{ 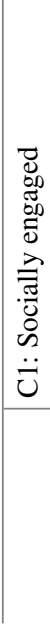 } & 뭉 & $\stackrel{n}{\varrho}$ & $\begin{array}{l}\bar{\sigma} \\
\infty \\
0\end{array}$ & & $\begin{array}{l}\overrightarrow{0} \\
0 \\
-\end{array}$ & $\begin{array}{l}\hat{A} \\
\infty \\
0 \\
0\end{array}$ & 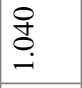 & $\begin{array}{l}n \\
\infty \\
0 \\
0\end{array}$ & 尺ิ & $\begin{array}{c}\infty \\
\infty \\
\infty \\
0 \\
0\end{array}$ & & \begin{tabular}{l}
$\infty$ \\
0 \\
0 \\
\hdashline \\
-
\end{tabular} & 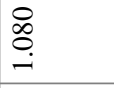 \\
\hline & 岳 & $\stackrel{n}{0}$ & $\begin{array}{l}0 \\
0 \\
0 \\
0\end{array}$ & & $\begin{array}{c}\vec{d} \\
\overrightarrow{0}\end{array}$ & $\stackrel{m}{0}$ & $\begin{array}{l}8 \\
\stackrel{\infty}{0} \\
0\end{array}$ & $\frac{\vec{\infty}}{\overrightarrow{0}}$ & 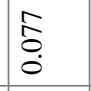 & $\underset{0}{\stackrel{N}{S}}$ & & $\begin{array}{l}0 \\
2 \\
0 \\
0\end{array}$ & ก̃ \\
\hline & \multirow{3}{*}{ 디 } & & * & & & * & & & & + & & & \\
\hline & & 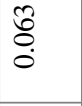 & $\stackrel{n}{\cdots}$ & & $\begin{array}{l}0 \\
0 \\
0 \\
\stackrel{0}{0}\end{array}$ & $\frac{n}{2}$ & ڤે & $\begin{array}{l}n \\
0 \\
0 \\
0 \\
1\end{array}$ & $\begin{array}{l}0 \\
0 \\
0 \\
0\end{array}$ & $\frac{\vec{m}}{\dot{0}}$ & & \begin{tabular}{l}
0 \\
\hdashline \\
0 \\
0
\end{tabular} & ڤ̂̀ \\
\hline & & 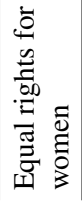 & 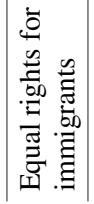 & $\mid$ & 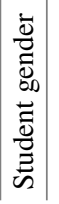 & 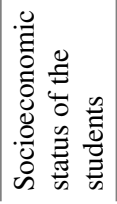 & 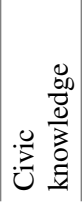 & 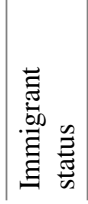 & 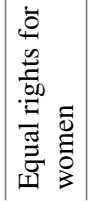 & 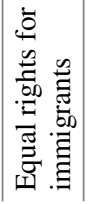 & $\mid$ & 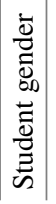 & 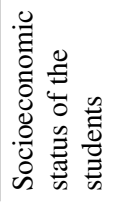 \\
\hline
\end{tabular}




\begin{tabular}{|c|c|c|c|c|c|c|c|c|c|c|c|c|c|}
\hline \multirow{4}{*}{ 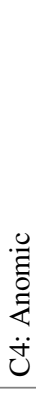 } & 号 & $\frac{n}{n}$ & $\begin{array}{l}\hat{n} \\
\hat{c} \\
i\end{array}$ & $\frac{n}{\mathfrak{n}}$ & $\begin{array}{l}n \\
n \\
o \\
0\end{array}$ & & $\begin{array}{l}\hat{2} \\
\stackrel{0}{0}\end{array}$ & $\begin{array}{l}0 \\
\tilde{O} \\
0 \\
0\end{array}$ & \begin{tabular}{l}
0 \\
\multirow{2}{*}{} \\
0
\end{tabular} & 官. & $\stackrel{\infty}{\stackrel{\infty}{0}}$ & $\underset{0}{\stackrel{0}{0}}$ & \\
\hline & $\sqrt[\omega]{\infty}$ & $\frac{n}{n}$ & 尚 & $\begin{array}{l}9 \\
\stackrel{0}{0}\end{array}$ & $\frac{P}{9}$ & & $\begin{array}{l}\stackrel{2}{~} \\
\text { ஸे }\end{array}$ & ले & $\begin{array}{l}\infty \\
\stackrel{1}{0} \\
0\end{array}$ & $\begin{array}{l}n \\
0 \\
0\end{array}$ & ते & $\frac{4}{2}$ & \\
\hline & & 苂 & & & 苂 & & & & * & $\stackrel{*}{*}$ & & $\stackrel{*}{*}$ & \\
\hline & 工I & $\begin{array}{l}\text { :े } \\
\stackrel{0}{0} \\
i \\
1\end{array}$ & $\underset{\mathbb{\Xi}}{\stackrel{\Xi}{0}}$ & 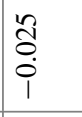 & $\begin{array}{l}8 \\
n \\
n \\
0 \\
1\end{array}$ & & $\begin{array}{l}\overrightarrow{\widehat{N}} \\
\hat{n} \\
i\end{array}$ & $\begin{array}{l}0 \\
0 \\
0 \\
0 \\
1\end{array}$ & $\begin{array}{l}0 \\
0 \\
0 \\
0 \\
i\end{array}$ & $\begin{array}{l}\stackrel{8}{\circ} \\
\stackrel{-}{-}\end{array}$ & 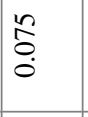 & $\begin{array}{l}\text { to } \\
n \\
0 \\
1\end{array}$ & \\
\hline \multirow{4}{*}{ 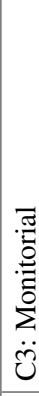 } & 응 & 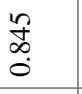 & 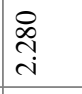 & $\frac{N}{\hat{N}}$ & $\begin{array}{l}\bar{\delta} \\
\infty \\
0 \\
\end{array}$ & & $\begin{array}{l} \pm \\
\\
0\end{array}$ & $\begin{array}{l}n \\
\infty \\
0 \\
0\end{array}$ & $\begin{array}{l}\vec{b} \\
\infty \\
0\end{array}$ & $\begin{array}{l}\stackrel{\infty}{g} \\
\stackrel{\sim}{i} \\
i\end{array}$ & $\underset{\overbrace{}}{\tilde{\sigma}}$ & 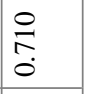 & \\
\hline & $\sqrt[\omega]{\infty}$ & \begin{tabular}{l}
$n$ \\
\hdashline
\end{tabular} & $\begin{array}{l}\text { సิ } \\
\text { ֶ̊ }\end{array}$ & $\begin{array}{l}\text { to } \\
\stackrel{0}{0} \\
0\end{array}$ & : & & $\begin{array}{l}\frac{7}{0} \\
\end{array}$ & $\begin{array}{l}\text { ஜे } \\
0 \\
0\end{array}$ & $\Xi$ & són & $\begin{array}{l}2 \\
0 \\
0\end{array}$ & వ্. & \\
\hline & & * & $\stackrel{*}{*}$ & & * & & * & & & $*$ & & $\begin{array}{l}* \\
* \\
*\end{array}$ & \\
\hline & 디 & $\begin{array}{c}\infty \\
0 \\
\stackrel{0}{0} \\
1\end{array}$ & $\begin{array}{c}\stackrel{J}{d} \\
\infty \\
0 \\
0\end{array}$ & $\begin{array}{l}\text { ડे. } \\
\text { ஸे } \\
\text { i }\end{array}$ & $\begin{array}{l}\overline{\tilde{N}} \\
\tilde{0} \\
1\end{array}$ & & $\begin{array}{l}\infty \\
\infty \\
+ \\
0 \\
1 \\
1\end{array}$ & $\stackrel{m}{\stackrel{m}{0}}$ & $\begin{array}{l}\frac{i}{n} \\
\frac{0}{0} \\
1\end{array}$ & $\begin{array}{c}\stackrel{2}{\circ} \\
\text { ○. }\end{array}$ & $\tilde{\overbrace{}}$ & $\begin{array}{l}\text { I } \\
\text { m̦ } \\
\text { i }\end{array}$ & \\
\hline \multirow{4}{*}{ 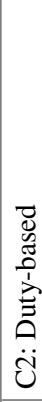 } & 으 & $\stackrel{\vartheta}{\sigma}$ & $\underset{ }{\stackrel{N}{(}}$ & $\begin{array}{l}-\overrightarrow{0} \\
\infty \\
0\end{array}$ & $\begin{array}{l}\text { do } \\
\stackrel{0}{0} \\
0\end{array}$ & & $\stackrel{\overbrace{}}{0}$ & すे & $\stackrel{n}{\sigma}$ & $\begin{array}{l}\stackrel{0}{0} \\
\stackrel{6}{i} \\
i\end{array}$ & $\stackrel{n}{2}$ & $\begin{array}{l}\hat{0} \\
\infty \\
0\end{array}$ & \\
\hline & 㭊 & $\begin{array}{l}\bar{\infty} \\
\stackrel{0}{0} \\
\end{array}$ & $\begin{array}{l}\infty \\
\infty \\
\\
0\end{array}$ & $\begin{array}{l}\mathscr{2} \\
0 \\
0\end{array}$ & : & & $\begin{array}{l}\stackrel{0}{0} \\
\vdots \\
0\end{array}$ & : & ָ̃. & 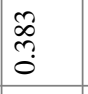 & $\stackrel{8}{\circ}$ & ț & \\
\hline & & & & + & * & & & & & $*$ & & * & \\
\hline & 피 & $\frac{O}{0}$ & $\underset{\mathrm{J}}{\stackrel{J}{0}}$ & $\frac{g}{\frac{g}{0}}$ & $\begin{array}{l}\stackrel{?}{\hat{n}} \\
\stackrel{0}{i} \\
1\end{array}$ & & $\begin{array}{l}\overrightarrow{8} \\
\vdots \\
0\end{array}$ & \begin{tabular}{l}
\multirow{2}{*}{} \\
0 \\
0 \\
1
\end{tabular} & $\begin{array}{l}\stackrel{\circ}{0} \\
\stackrel{0}{0}\end{array}$ & $\begin{array}{l}\vec{\circ} \\
\stackrel{0}{0}\end{array}$ & 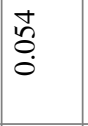 & $\frac{\mathfrak{f}}{\stackrel{+}{i}}$ & \\
\hline \multirow{5}{*}{ 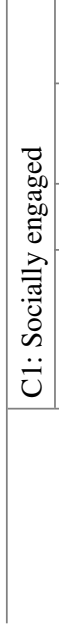 } & 㰻 & ఠ్ & 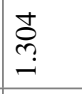 & هి & $\begin{array}{l}\widehat{\delta} \\
\infty \\
0 \\
0\end{array}$ & & $\begin{array}{l}\vec{\infty} \\
0 \\
-\end{array}$ & 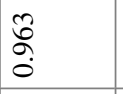 & 今్ & $\underset{m}{\infty}$ & $\underset{9}{\stackrel{P}{I}}$ & $\stackrel{0}{0}$ & \\
\hline & 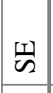 & $\underset{0}{\stackrel{N}{0}}$ & તิ & ôे & ڤ్రి & & $\begin{array}{l}9 \\
\overrightarrow{0} \\
0\end{array}$ & 㔯 & $\overrightarrow{0}$ & 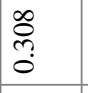 & $\stackrel{\Re}{0}$ & $\begin{array}{l}\mathscr{2} \\
\stackrel{0}{0} \\
0\end{array}$ & \\
\hline & & $\stackrel{\text { 奠 }}{*}$ & & & * & & & & 悉 & 蒂 & * & & \\
\hline & 디 & $\begin{array}{l}\text { తి } \\
\text { ஸे }\end{array}$ & $\begin{array}{l}\stackrel{0}{0} \\
\text { గi } \\
0\end{array}$ & $\begin{array}{l}\text { ¿ొ } \\
\text { రి. } \\
0\end{array}$ & $\frac{\substack{+\\
}}{1}$ & & $\begin{array}{l}\infty \\
\stackrel{\infty}{0} \\
0\end{array}$ & 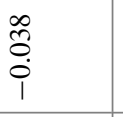 & 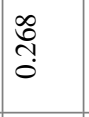 & $\stackrel{n}{=}$ & $\stackrel{\overrightarrow{0}}{\overrightarrow{0}}$ & $\begin{array}{l}0 \\
\stackrel{0}{0} \\
0\end{array}$ & \\
\hline & & 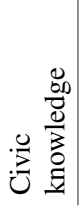 & 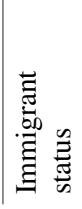 & 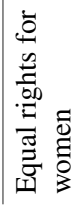 & 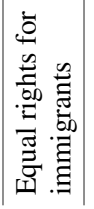 & | & 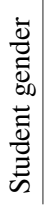 & 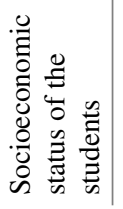 & 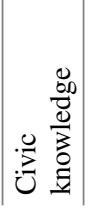 & 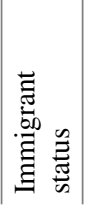 & 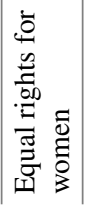 & 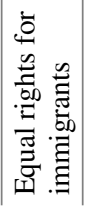 & 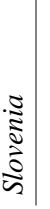 \\
\hline
\end{tabular}




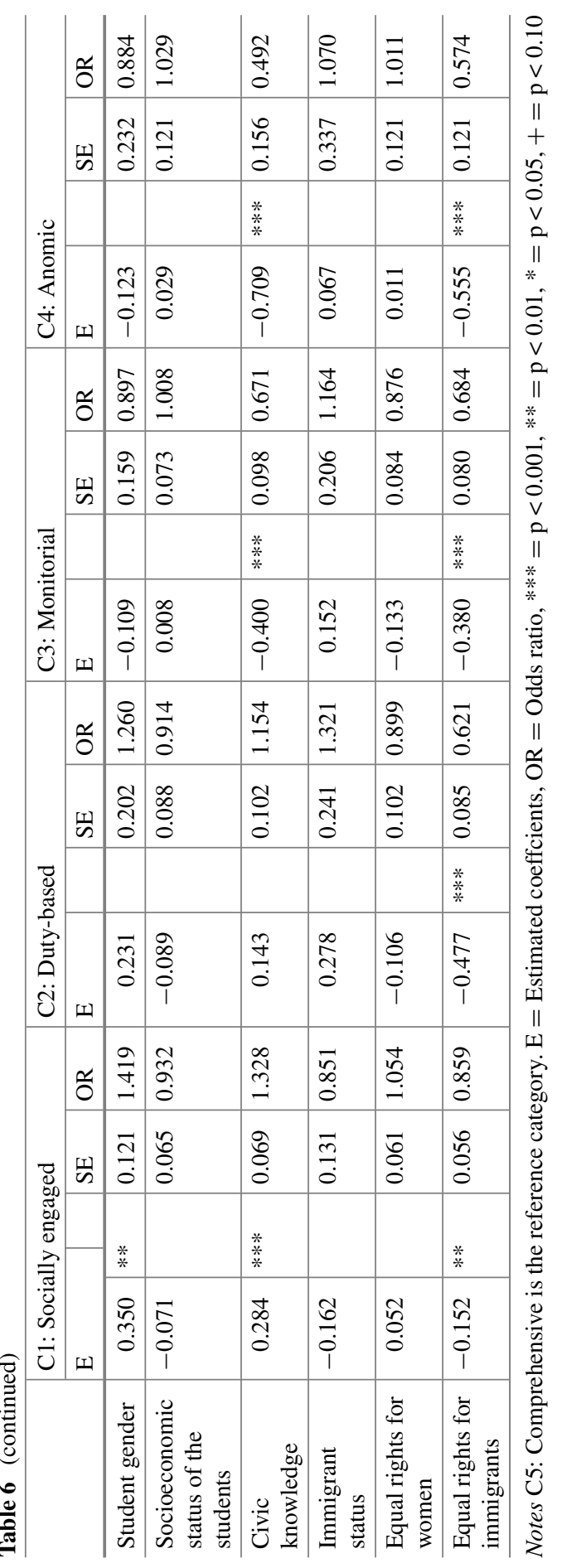




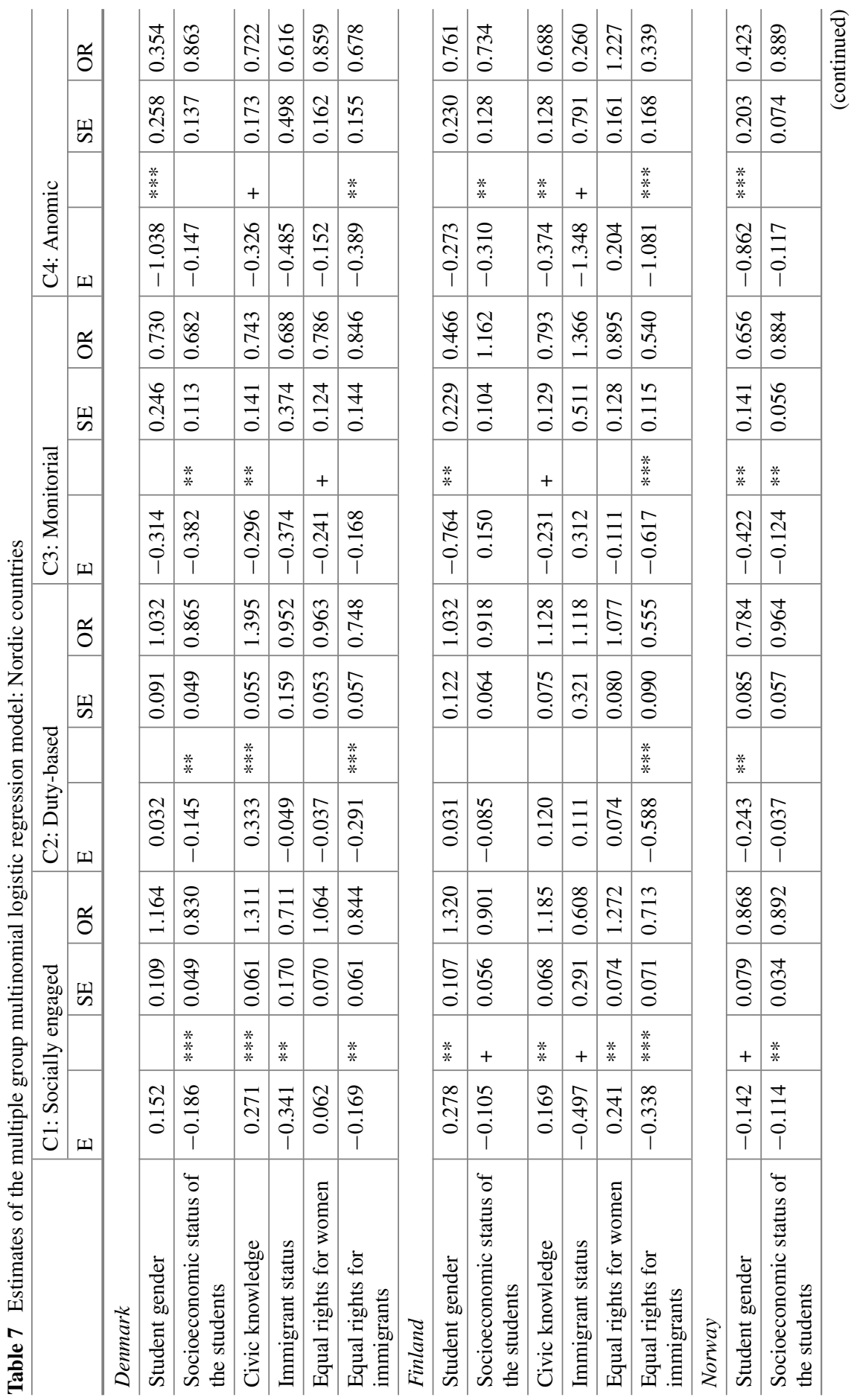




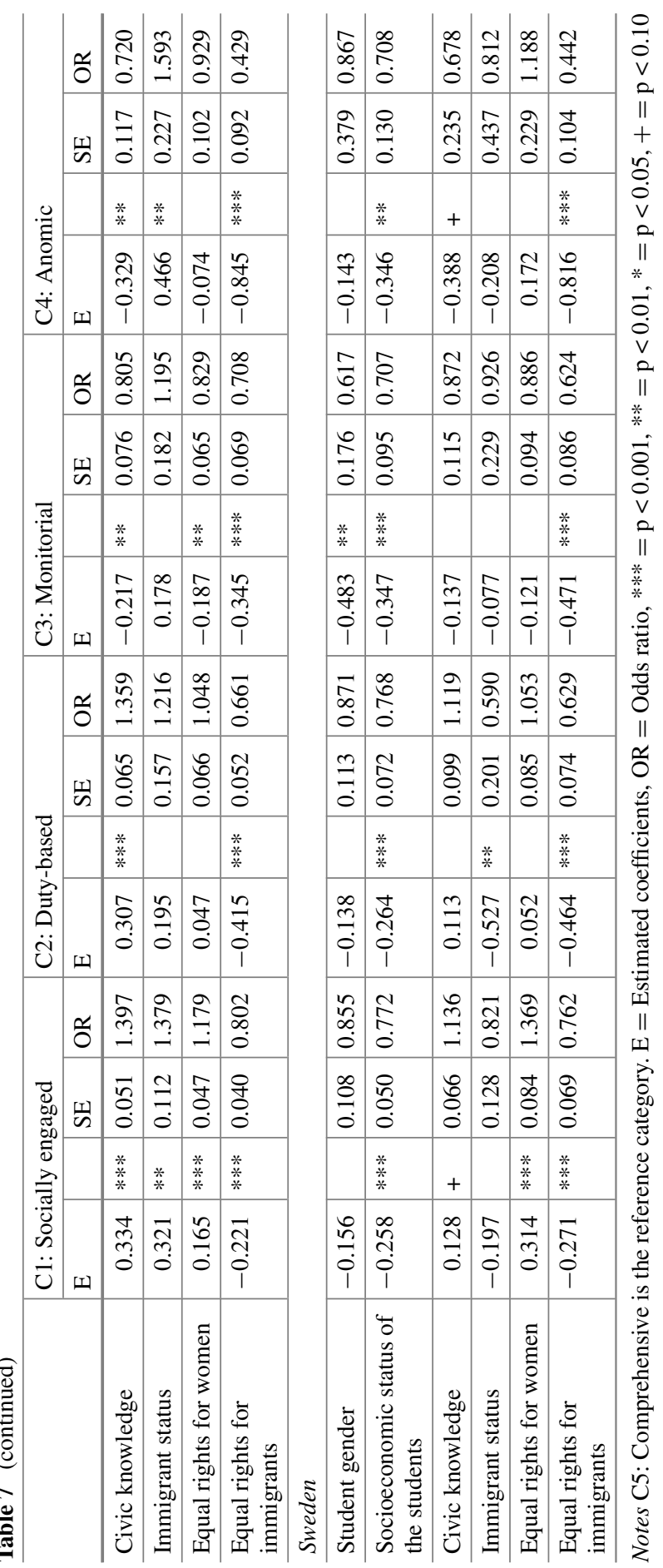




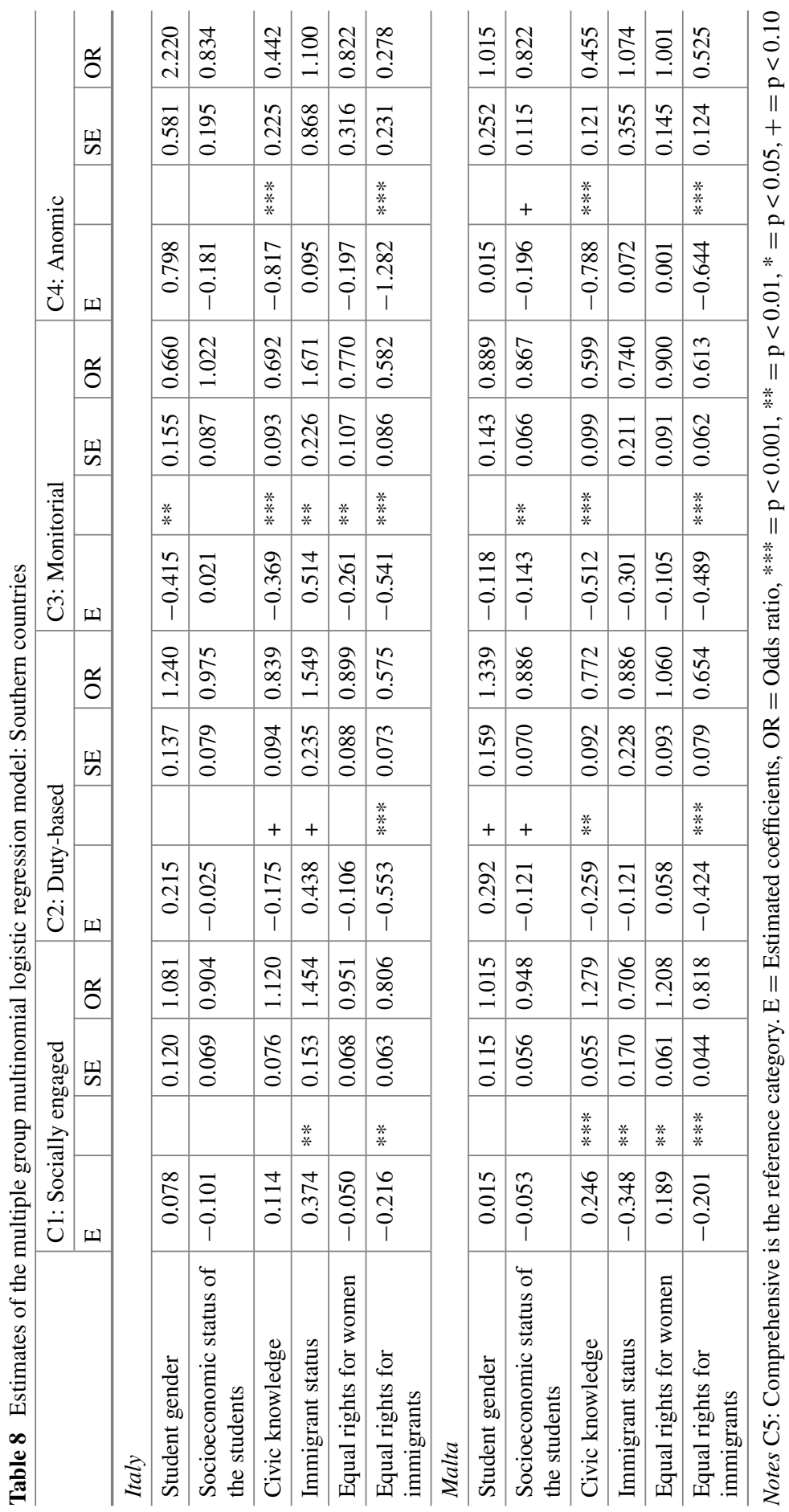




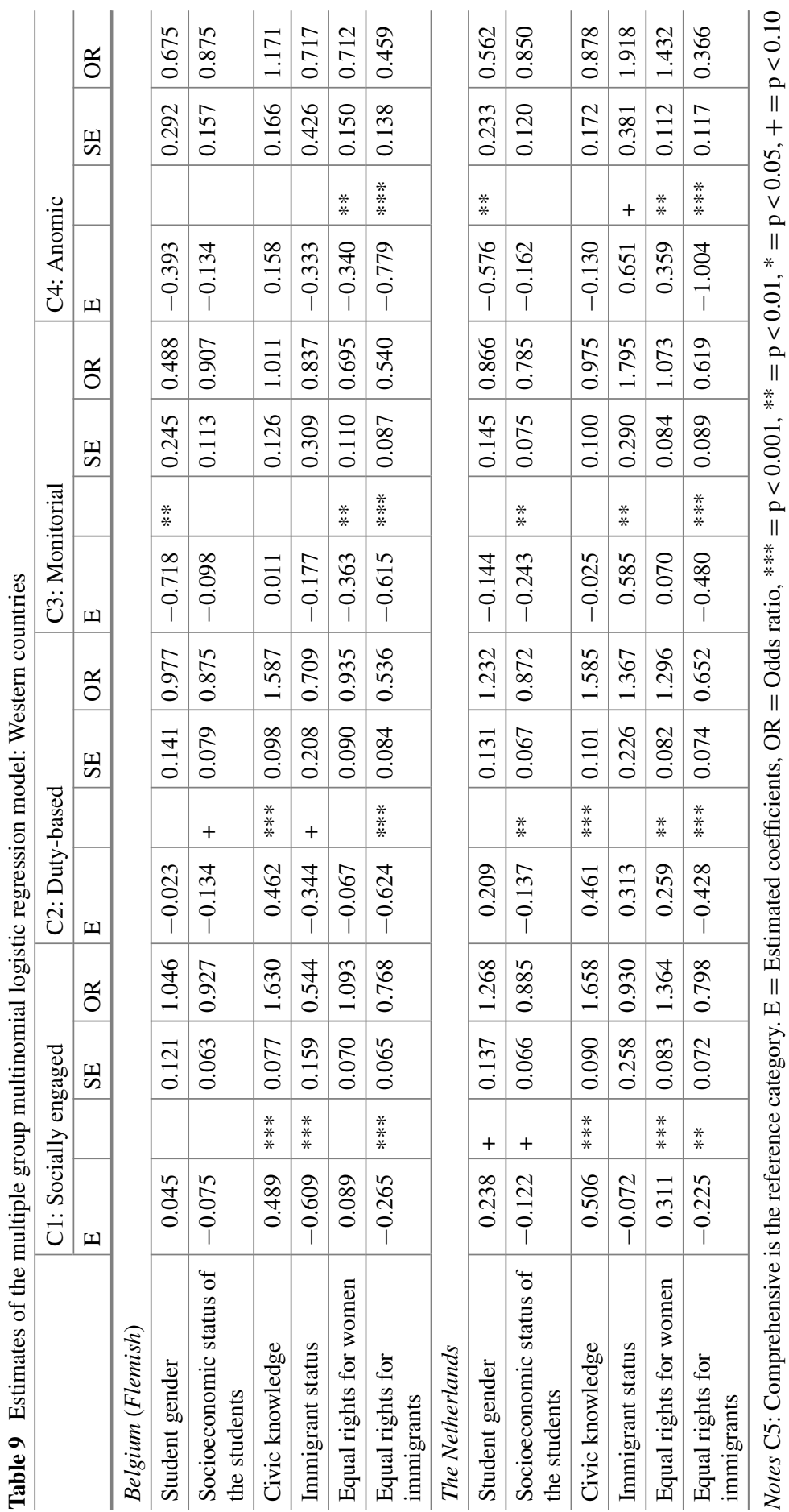




\section{References}

Almond, G., \& Verba, S. (1963). The civic culture. Princeton, NJ: Princeton University Press.

Barber, C., \& Ross, J. (2018). Cross-cohort changes in adolescents' civic attitudes from 1999 to 2009: An analysis of sixteen countries. Child Indicators Research, 11(2), 681-703. https://doi. org/10.1007/s12187-017-9452-0.

Bolloten, B., \& Richardson, R. (2015). The great British values disaster-education, security and vitriolic hate. London: Institute of Race Relations

Brodie, J. (2004). Introduction: globalization and citizenship beyond the national state. Citizenship Studies, 8(4), 323-332. https://doi.org/10.1080/1362102052000316945.

Brown, T. A. (2014). Confirmatory factor analysis for applied research. Methodology in the social sciences. London, United Kingdom: Guilford.

Council of Europe. (2010). Charter on education for democratic citizenship and human rights education. Strasbourg, France: Author.

Dalton, R. J. (2008). Citizenship norms and the expansion of political participation. Political Studies, 56(1), 76-98. https://doi.org/10.1111/j.1467-9248.2007.00718.x.

Dejaeghere, Y., \& Hooghe, M. (2009). Brief report: Citizenship concepts among adolescents. Evidence from a survey among Belgian 16-year olds. Journal of Adolescence, 32(3), 723-732. https://doi.org/10.1016/j.adolescence.2009.01.007.

Ekman, J., \& Amnå, E. (2012). Political participation and civic engagement: Towards a new typology. Human affairs,22(3), 283-300.

Freitag, M., \& Rapp, C. (2015). The personal foundations of political tolerance towards immigrants. Journal of Ethnic and Migration Studies, 41(3), 351-373. https://doi.org/10.1080/1369183X. 2014.924847.

Gibson, J. L. (2007). Political intolerance in the context of democratic theory. In R. Goodin (Ed.), The Oxford handbook of political science (pp. 323-341). Oxford, United Kingdom: Oxford University Press.

Gonzalez, E. J. (2012). Rescaling sampling weights and selecting mini-samples from largescale assessment databases. IERI Monograph Series Issues and Methodologies in Large-Scale Assessments, 5, 115-134.

Green, A., Preston, J., \& Janmaat, J. (2006). Education, equality and social cohesion: A comparative analysis. Berlin: Springer.

Hanh, C. L. (1998). Becoming political: Comparative perspectives on citizenship education. Albany, NY: SUNY Press.

Heater, D. (1999). What is citizenship? Cambridge, United Kingdom: Polity Press.

Hooghe, M., \& Oser, J. (2015). The rise of engaged citizenship: The evolution of citizenship norms among adolescents in 21 countries between 1999 and 2009. International Journal of Comparative Sociology, 56(1), 29-52. https://doi.org/10.1177/0020715215578488.

Hooghe, M., Oser, J., \& Marien, S. (2016). A comparative analysis of 'good citizenship': A latent class analysis of adolescents' citizenship norms in 38 countries. International Political Science Review, 37(1), 115-129. https://doi.org/10.1177/0192512114541562.

IBM. (2015). IBM SPSS statistics for windows, Version 23.0. Armonk, NY: IBM Corp.

IEA. (2017). IDB analyzer. Amsterdam, the Netherlands: International Association for the Evaluation of Educational Achievement (IEA). http://www.iea.nl/data.html.

Isac, M. M., Sandoval-Hernández, A., \& Miranda, D. (2018). Teaching tolerance in a globalized world: An introduction. In A. Sandoval-Hernandez, M. M. Isac, \& D. Miranda (Eds.), Teaching tolerance in a globalized world (pp. 1-10). IEA Research for Education, Volume 4. Cham, Switzerland: Springer.

Isac, M. M., Palmerio, L., \& van der Werf, M. P. C. (2019). Indicators of (in)tolerance toward immigrants among European youth: An assessment of measurement invariance in ICCS 2016. Large-scale Assessments in Education, 7(6). https://doi.org/10.1186/s40536-019-0074-5.

Midtbøen, A. H. (2015). Citizenship, integration and the quest for social cohesion: nationality reform in the Scandinavian countries. Comparative Migration Studies, 3(1), 3. 
Muthén, L. K., \& Muthén, B. (2017). Mplus user's guide (8th ed.). Los Angeles, CA: Muthén \& Muthén.

Mylonas, Y. (2012). Media and the economic crisis of the EU: The 'culturalization' of a systemic crisis and Bild-Zeitung's framing of Greece. TripleC: Communication, Capitalism \& Critique, $10(2), 646-671$.

O'Sullivan, M., \& Pashby, K. (2008). Citizenship education in the era of globalization: Canadian perspectives. Brock Education Journal, 17(1). https://doi.org/10.26522/brocked.v17i1.31.

Putnam, R. D. (2007). E pluribus unum: Diversity and community in the twenty-first century the 2006 Johan Skytte prize lecture. Scandinavian Political Studies, 30(2), 137-174. https://doi.org/ 10.1111/j.1467-9477.2007.00176.x.

Reichert, F. (2016). Who is the engaged citizen? Correlates of secondary school students' concepts of good citizenship. Educational Research and Evaluation, 22(5-6), 305-332. https://doi.org/10. 1080/13803611.2016.1245148.

Reid, A., Gill, J., \& Sears, A. (Eds.). (2010). Globalisation, the nation-state and the citizen: Dilemmas and directions for civics and citizenship education. New York, NY: Routledge.

Rutkowski, L., Gonzalez, E., Joncas, M., \& von Davier, M. (2010). International large-scale assessment data: Issues in secondary analysis and reporting. Educational Researcher, 39(2), 142-151. https://doi.org/10.3102/0013189X10363170.

Sampermans, D., Maurissen, L., Louw, G., Hooghe, M., \& Claes, E. (2017). ICCS 2016 rapport Vlaanderen: Een onderzoek naar burgerschapseducatie in Vlaanderen [ICCS 2016 Flanders report: A study of citizenship education in Flanders]. Leuven, Belgium: Centrum voor Politicologie, KU Leuven.

Schattle, H. (2012). Globalization and citizenship. Lanham, MD: Rowman \& Little-field.

Schierup, C. U., \& Ålund, A. (2011). The end of Swedish exceptionalism? Citizenship, neoliberalism and the politics of exclusion. Race \& Class, 53(1), 45-64.

Schulz, W., Ainley, J., Fraillon, J., Losito, B., Agrusti, G., \& Friedman, T. (2018a). ICCS 2016 international report: Becoming citizens in a changing world. Cham, Switzerland: Springer.

Schulz, W., Carstens, R., Losito, B., \& Fraillon, J. (Eds.). (2018b). ICCS 2016 technical report. Amsterdam, the Netherlands: International Association for the Evaluation of Educational Achievement (IEA).

Sherrod, L. R., \& Lauckhardt, J. (2009). The development of citizenship. In L. S. R. M. Lerner (Ed.), Handbook of adolescent psychology (pp. 372-407). Hoboken, NJ: Wiley.

Stapleton, L. M. (2013). Incorporating sampling weights into single- and multilevel analyses. In L. Rutkowski, M. von Davier, \& D. Rutkowski (Eds.), Handbook of international large scale assessment: Background, technical issues, and methods of data analysis (pp. 363-388). Boca Raton, FL: Chapman and Hall/CRC.

Sullivan, J. L., Marcus, G. E., Feldman, S., \& Piereson, J. E. (1981). The sources of political tolerance: A multivariate analysis. American Political Science Review, 75(1), 92-106. https://doi. org/10.2307/1962161.

Sullivan, J. L., \& Transue, J. E. (1999). The psychological underpinings of democracy: A selective review of research on political tolerance, interpersonal trust, and social capital. Annual Review of Psychology, 50(1), 625-650. https://doi.org/10.1146/annurev.psych.50.1.625.

Torres, C. A. (2002). Globalization, education, and citizenship: Solidarity versus markets? American Educational Research Journal, 39(2), 363-378. https://doi.org/10.3102/00028312039002363.

Vogt, W. P. (1997). Tolerance \& education: Learning to live with diversity and difference. London, United Kingdom: Sage.

Wang, J., \& Wang, X. (2012). Structural equation modeling: Applications using Mplus. Chichester, United Kingdom: Wiley. https://doi.org/10.1002/9781118356258.

Westheimer, J., \& Kahne, J. (2007). Introduction. Equity \& Excellence in Education, 40(2), 97-100. https://doi.org/10.1080/10665680701228847. 
Andrés Sandoval-Hernández is Head of the Department of Education at the University of Bath in the UK. Previously, he worked as Head of the Research and Analysis Unit at the IEA and held various academic positions at the Universidad Iberoamericana and FLACSO. His research interests include comparative analysis of education systems using large-scale assessment data with a focus on educational inequalities and civic education.

Ellen Claes is Associate Professor at the faculty of Social Sciences of the KU Leuven, Belgium. She is part of the Centre for Political Science Research since 2005 and responsible for the Master in Social Science Education since 2013. In her work, Ellen takes a didactic perspective on political science, exploring the effects secondary schools have in shaping democratic knowledge, skills, and attitudes of young people. Recent studies focus on the civic and intercultural competencies of (student) teachers.

Nicola Savvides is Associate Professor in International Education at the University of Bath where she is Director of Studies for the MA International Education and Globalisation. Her research interests include European, international and intercultural dimensions in education in policy and practice. Nicola is an Ordinary Member of the British Association for International and Comparative Education (BAICE) Executive Committee (second term) and was former Convenor of the British Educational Research Association's (BERA's) Comparative and International Education SIG for 10 years. She holds an ESRC-funded doctorate in Comparative and International Education from the University of Oxford.

Maria Magdalena Isac is a Researcher at the Catholic University of Leuven (KU Leuven) and at INVALSI. Prior to these assignments, she held research positions at the University of Groningen and the European Commission. Magda's research is focused in the area of comparative evaluation of educational systems, with special emphasis on understanding how different formal and informal educational approaches contribute to young people's citizenship learning.

Open Access This chapter is licensed under the terms of the Creative Commons AttributionNonCommercial 4.0 International License (http://creativecommons.org/licenses/by-nc/4.0/), which permits any noncommercial use, sharing, adaptation, distribution and reproduction in any medium or format, as long as you give appropriate credit to the original author(s) and the source, provide a link to the Creative Commons license and indicate if changes were made.

The images or other third party material in this chapter are included in the chapter's Creative Commons license, unless indicated otherwise in a credit line to the material. If material is not included in the chapter's Creative Commons license and your intended use is not permitted by statutory regulation or exceeds the permitted use, you will need to obtain permission directly from the copyright holder.

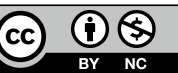

